\title{
Fulfilment of Scripture and Jesus' Teachings in Matthew
}

\author{
Author: \\ R. Alan Culpepper ${ }^{1}$ \\ Affiliation: \\ ${ }^{1}$ McAfee School of Theology, \\ Mercer University, \\ United States \\ Correspondence to: \\ Alan Culpepper \\ Email: \\ culpepper_ra@mercer.edu \\ Postal address: \\ McAfee School of Theology, \\ 3001 Mercer University \\ Drive, Atlanta, GA 30341, \\ United States

\section{Dates:} \\ Received: 07 May 2015 \\ Accepted: 10 July 2015 \\ Published: 13 Aug. 2015 \\ How to cite this article: \\ Culpepper, R.A., 2015, \\ 'Fulfilment of Scripture and \\ Jesus' Teachings in Matthew', \\ In die Skriflig 49(2), Art. \\ \#1986, 8 pages. http:// \\ dx.doi.org/10.4102/ids. \\ v49i2.1986

\section{Copyright:} \\ (C) 2015. The Authors. \\ Licensee: AOSIS \\ OpenJournals. This work is \\ licensed under the Creative \\ Commons Attribution \\ License.
}

\section{Read online:}

Scan this QR code with your smart phone or mobile device to read online.
One of the most intriguing aspects of the experience of reading the gospels, for both beginning students and those who have been at it for decades, is the growing awareness of how the gospels convey their message. Our attention is usually focused first on what the message is: the storyline, the plot, the climax or resolution, and its implications. As we continue to read and reread, we may find that we begin to grow interested in various features of the narrative, such as its organisation, collections of material (parables or miracle stories), repetitions, the ways characters are represented or the narrator's comments. These are not incidental features of the gospel narrative. On the contrary, they are the elements with which it is constructed and that guide the reader's experience of the narrative. In this article we will explore how Matthew leads its Jewish-Christian readers, sometime late in the 1st century and during the process of the separation of early believers from the synagogue, to accept Jesus' teachings as a new teaching on righteousness and functionally at least a new Torah. Specifically, we will analyse the role of repetition and redundancy in Matthew's narrative rhetoric in relation to this theme.

Vervulling van die Skrif en Jesus se onderrig in Matteus. Een van die boeiendste aspekte wat beginnerstudente sowel as ervare lesers met die bestudering van die evangelies ondervind, is die groeiende bewustheid van hoe die boodskap oorgedra word. Normaalweg word die aandag eerstens op die boodskap gevestig: die storielyn, die verloop, die hoogtepunt en die ontknoping, en die implikasies daarvan. Met die lees en herlees daarvan word 'n groeiende belangstelling ondervind in die onderskeie kenmerke van die narratief soos die samestelling daarvan, die tipe gegewens (gelykenisse of wonderwerke), herhalings, die manier hoe die karakters voorgestel word en die verteller se kommentaar. Hierdie is nie toevallige kenmerke van die evangelie-narratief nie. Inteendeel, dit is die elemente waaruit dit saamgestel is en wat die leser se ervaring van die narratief begelei. In hierdie artikel word die wyse ondersoek waarop Matteus, in die eerste eeu na Christus en gedurende die skeidingsproses van die vroeë gelowiges uit die sinagoge, die Joodse-Christenlesers lei om Jesus se onderrig as 'n nuwe lering oor regverdigheid en, wat meer is, 'n nuwe Torah te aanvaar. 'n Spesifieke analise word gemaak oor die rol van herhaling en toutologie in Matteus se narratiewe retoriek wat verband hou met hierdie tema.

\section{Repetition and redundancy ${ }^{1}$}

In her University of Chicago dissertation, 'Matthew's narrative web: Over, and over, and over again', Janice Capel Anderson (1994) explores the functions and effects of repetition and redundancy in Matthew. Repetition can occur at any number of levels and involve various elements of the narrative, for example verbal repetition, repetition of similar settings, repetition of similar events or repetition of similar comments by the narrator. Especially in an oral context, in which the gospels were probably read or performed for audiences, repetition was an important means of communicating emphasis and insuring that the narrative was being understood. Redundancy involves repetitions, but it has a more technical meaning: 'Redundancy is the availability of information from more than one source' (Anderson 1994:36). Anderson cites C. Cherry's definition of redundancy, not as a feature of narratives, but as a property of communication: 'Briefly, redundancy is a property of language, codes, and sign systems which arises from a superfluity of rules, and which facilitates communications in spite of all the factors of uncertainty acting against it' (Anderson 1994:36, n. 3; Cherry 1957:18-19). Like manned spacecraft that have redundant systems to insure that even if one system fails, another will guarantee that the spacecraft is capable of sustaining human life and completing its mission, redundancy in

1.This article is offered as a tribute to Jan du Rand, whose work has advanced my own understanding of John and introduced the international community to South African scholarship and vice versa. I am particularly grateful for fond memories of visits in each other's homes, hours of conversation, and evenings bicycling together. 
narratives insures that readers or hearers will be guided to understand the text they are hearing or reading. For the role of redundancy in literary theory, Anderson drew on the pioneering work of C.H. Lohr (1961), Susan Rubin Suleiman (1980), and Susan Wittig (1973). By the time her dissertation was published, Meir Sternberg's The Poetics of Biblical Narrative (1988) had appeared with its keen observations on the functions of repetition in the Hebrew Scriptures. R.D. Witherup (1992; 1993) was exploring the role of redundancy in the Acts.

Suleiman (1980:119) employed Roland Barthes' (1974:4) distinction between "readable" (lisible) and 'writable' (scriptible) texts. The former texts limit the range of meaning by employing conventional grammar, logic and genres, whilst the latter are innovative, less defined and therefore open to various interpretations. Redundancy is therefore 'highly characteristic of "readable" texts' (Anderson 1994:40). Anderson's analyses of the double and triple stories in Matthew make a significant contribution by showing how redundancy functions in the central section of Matthew. The importance of each of the stories' elements is also established through context, repetition and variation (Anderson 1994:43).

Based on Anderson's groundbreaking work, we may make the following complementary observations: The effect of a narrative texture marked by repetition and redundancy is that it propels the reader to greater sensitivity to Matthew's progressive determination of character, development of conflicts and definition of themes. Repetition contributes to recognition: the reader recognises significant or typical settings, actions, pronouncements and conflicts. Variation produces movement: the story introduces new elements, and the reader is required to integrate the new elements into the previous patterns. At least for reading Matthew, the reader is like 'the scribe trained for the kingdom of heaven' (13:52). In other words, the reader should bring out the new as well as the old from the story. The degree of dissonance between new and old and the ratio of variation to repetition determine whether the story will give the reader an easy ride or a challenging one. Stories that have a lower degree of dissonance and a higher ratio of repetition demand less of readers than stories that have a greater level of dissonance and higher ratio of variation. Context allows integration: the more specific and informative the context, the more successful the reader will be in evaluating a scene and integrating it, with its new elements, into the reading experience. To use Roland Barthes' term (1974:4) once more, the more definite the context the more 'readable' it is.

Redundancy in narrative texts, however, involves considerably more than just predictability and repetition. Repetition conveys emphasis, signals importance and invites comparison and contrast. Because of the multiplicity of ways in which information can be conveyed in a narrative text, the possibilities for redundancy are intriguing. At least the following levels merit attention:
1. Verbal repetition: Words and phrases can be repeated at various points in the narrative.

2. Formal elements: The gospels are largely composed of the repetition and variation of a limited number of formal units or type scenes: exorcisms, feedings, healings, sea stories and teaching scenes.

3. Events (plot) and existents (characters, settings): These are Seymour Chatman's terms for some of the elements of a story. Information can be conveyed to the reader by different aspects of the story. The same information can be conveyed, for example, by the development of the plot and by the patterns of characterisation (see Culpepper 2013).

4. Implicit commentary (imagery, symbolism, irony): Various devices may convey to the reader that things are other than or more than they seem to be. Whether delicately or forcefully, imagery, symbolism and irony invite the reader to grasp meanings that are not explicitly stated. Information conveyed by these means may again either reinforce or challenge information or meanings that the reader obtains from other elements of the narrative.

5. Embedded stories: Within the gospel narratives, Jesus tells stories (parables and allegories) that function variously as examples, polemical devices and orientation for the reader regarding the characters and plot of the larger narrative.

6. Story and narrative: The narrator, by explicit commentary, may convey information to the reader, which again may or may not be confirmed by messages conveyed by the story itself. In the case of reliable biblical narrators, of course, the stories confirm the explicit commentary, but may say more than the commentary.

7. Intertextual allusions and quotations: Particularly important in Matthew are the frequent explicit quotations from the prophets and the repeated use of allusions to the Hebrew Scriptures in the course of narrating Jesus' story as well as in his teachings.

8. Genre and canon: The three synoptic gospels tell the story of Jesus with significant repetitions and variations, whilst the Fourth Gospel tells the story with major differences from the synoptics. The New Testament canon itself is therefore redundant.

These levels of possible redundancy offered the gospel writers many options for insuring that their message would be understood by hearers and readers. The Gospel of Matthew, which is both repetitious and redundant at many points, invites the reader to look carefully for ways this redundancy can be illuminating.

\section{Redundancy in the fulfilment of Scripture in Matthew ${ }^{2}$}

In the heading and the genealogy, the narrator links Jesus to persons in the Scriptures. The Gospel opens with references to Abraham and David, and a genealogy that ties Jesus to

2.All references to the Gospel of Matthew will be indicated only by chapters and verses. 
the scriptural heritage of Israel (Anderson 1994:48-53). Anderson's identification of the genealogy as a part of the narrator's direct commentary is helpful (Anderson 1994:48$49)$, but in view of the thesis developed below we may also note that a major function of this commentary is to link Jesus with Scripture and thus lead the reader to accept the claim that Jesus came to fulfil Scripture. The fulfilment of Scripture, one of the leading Matthean themes, is then signalled by the repetition of fulfilment formulae. ${ }^{3}$ The narrator pauses to note fulfilment in the following references early in the Gospel:

1:22 'to fulfil what had been spoken by the Lord through the prophet'

2:15 'to fulfil what had been spoken by the Lord through the prophet'

2:17 'then was fulfilled what had been spoken through the prophet Jeremiah'

2:23 'so that what had been spoken through the prophets might be fulfilled'

3:3 'this is the one who of whom the prophet Isaiah spoke'

4:14 'so that what had been spoken through the prophet Isaiah might be fulfilled'

Events in the story take on added meaning when viewed against their Scriptural background. Like his biblical namesake, Joseph has revelatory dreams that guide coming events. The places named in the birth narrative provide a biblical geography that recapitulates much of Israel's history: Bethlehem, Egypt, Ramah, Nazareth (see Brown 1983:52-54; Stendahl 1964). The wise men reference the expectation of a coming Messiah (2:5-6). Drawing further the parallels between Jesus and Moses, Herod seeks the life of the child and kills the children of Bethlehem, just as Pharaoh had sought to kill the children of the Hebrews. Joseph's flight from Herod may evoke Moses' flight from Pharaoh (Ex 2:15-16). Joseph, responding to another dream, then brings his family 'out of Egypt' (2:15; itself an echo of Hs 11:1). The return to 'the land of Israel' recapitulates the Exodus and entry into the land. By evoking these parallels in his account of Jesus' infancy, Matthew prepares the reader to understand that Jesus fulfils the expectation of a new Moses (Dt 18:15, 18) who will lead the people of Israel.

The narrator introduces John the Baptist in the same idiom with a formula quotation (3:3). The characterisation of John the Baptist evokes the description of Israel's prophets, wearing clothing of camel's hair and a leather belt (2 Ki 1:8; Zch 13:4). Calling for repentance, John warns the Pharisees and Sadducees not to justify themselves by saying 'We have Abraham as our ancestor' (3:9).

The first words that Jesus speaks in the Gospel explain that his motive was fulfilment (3:15). Like Israel, Jesus passes through the Jordan. The voice from heaven at his baptism echoes the words of Psalm 2:7: 'You are my son.'

3.For discussion of the identification and origin of the fulfilment citations, see Viljoen (2007, especially pp. 302-305).
Like Israel, Jesus was tempted in the wilderness. Contrary to Gerhard Kittel's contention (1964:658) that 'there are no serious reasons for making the common connection of the forty days with the forty years of Israel in the wilderness', recognition of this connection is essential for Matthew's purposes. As Stanley Saunders (2010:23) notes, 'In these verses Matthew moves us, with Jesus, across the landscapes of Israel's hopes and frustrations and through the spaces of God's power and presence.' The 40 days of temptation recall also the 40 days Moses was on Mount Sinai (Ex 24:18; 34:28; Dt 9:9, 18) during which he neither ate nor drank and Elijah's forty-day journey to Mount Horeb (1 Ki 19:8; Balz 1972:137-139; Luz 2007:151), setting up Jesus' claim that he fulfilled the law and the prophets' $(5: 17)$. By implication, Jesus' obedience in the wilderness therefore stands in contrast to Israel's failure. Jesus answers the tempter at each point with quotations from Scripture $(4: 4,7,10)$, and even the Devil quotes Scripture (4:6). Jesus' withdrawal to Galilee to begin his ministry in Capernaum 'in the territory of Zebulun and Naphtali', continues the biblical geography of his infancy and cloaks Jesus' ministry in Isaiah's prophecy of the coming of a Davidic king to lead the people (Is 9:1-2, 6-7). At the Sea of Galilee, Jesus' call to the first disciples echoes Elijah's call of Elisha (1 Ki 19:21). Throughout its account of Jesus' baptism, temptation, calling of the disciples and early ministry (especially 3:3; 4:4, 6, 7, 10, 15-16) Matthew maintains the continuous underlying claim of the fulfilment of the Scriptures. Jesus' arrival fulfilled the law and the prophets, and Jesus' words and actions 'fulfil all righteousness' (Table 1).

The use of redundancy in the early chapters to emphasise that Jesus fulfilled the Scriptures is obvious and powerful (cf. Viljoen 2007:314-321). The theme appears in the opening words (the heading), the genealogy that establishes Jesus' identity, the biblical motif of revelatory dreams, parallels with biblical characters and events (Joseph, Pharaoh, Moses), biblical place names, the repetition of the narrator's fulfilment formula, frequent quotations from Scripture, and recapitulation of Israel's history. More formally, Matthew develops this theme using sequence (primacy or priority - the heading and genealogy), explicit commentary (the fulfilment formulae), explicit intertextuality (quotations and allusions to Scripture), and implicit intertextuality and typology (patterning by the use of names, characterisation, geography and events). These elements function constructively in fascinating ways when the action of the story, in this case the threat to the life of the child, echoes Pharaoh's killing of the Israelite children and leads to Joseph's dream (resonating with the dreams of the patriarch Joseph), his flight to Egypt and then his return, which the narrator relates to Hosea's report, 'Out of Egypt have I called my son' (11:1), by means of a formula quotation (2:15). 4.Luz (2007:151) observes that 'in Judaism there is, apart from Moses and Elijah,
mention of a forty-day fast only with Abraham (Apoc. Abr. 12.1, following 1 Kgs 19:8)'. 
TABLE 1: Fulfillment of scripture in Matthew 1-4.

\begin{tabular}{lll}
\hline Fulfillment & Matthew & Old Testament \\
\hline Implicit & & David, Abraham \\
Heading & $1: 1$ & \\
Genealogy & $1: 2-17$ & Gn 37:5, 6, 9, 10; 40:5, 9, 16; 41:7, 11, 12, 15, 17, 22, 32 \\
Dreams & $1: 20 ; 2: 12,13,19,22$ & Jerusaelm, Bethlehem, Ramah, Israel, Galilee, Nazareth \\
Biblical Geography & $2: 1,5-6,8,16,18,21,22,23$ & Hos 11:1 \\
Egypt & $2: 13,14,15,19$ & Ex 1:22; $2: 15,23 ; 3: 8,10$ \\
Moses Typology & $2: 13-16,19-21$ & Isa 40:3; 2 Ki 1:8; Zch 13:4 \\
John the Baptist & $3: 3-4$ & Ex 15:25; 16:24; 20:20 \\
Temptations in the Wilderness & $4: 1-16$ & Ex 24:18; 34:28; Dt 9:9, 18; Deut 8:16 \\
Forty Days & $4: 2$ & 1 Ki 19:21 \\
Call of the First Disciples & $4: 18-22$ & \\
Explicit & & Is 7:14; Mi 5:2; 2 Sa 5:2; Hos 11:1; Jer 31:15; Is 40:3; Is 9:1-2 \\
Fulfillment Formulae & $1: 22 ; 2: 5,15,17,23: 3: 3 ; 4: 14$ & Dt 8:3; Ps 91:11; Dt 6:16, 13; Is 9:1-2 \\
Jesus' Words & $3: 15 ; 4: 4,7,10$ (cf. also 5:17) &
\end{tabular}

\section{The fulfilment of Scripture and the authority of Jesus' words}

The Sermon on the Mount marks the beginning of a new phase of Jesus' ministry and a significant turning point in the Gospel. For our purposes, it is important to note how Matthew continues the theme of fulfilment whilst introducing the new theme of the authority of Jesus' words. The setting is Mosaic: Jesus goes up on a mountain to give a new teaching on righteousness. Following the beatitudes, Jesus affirms that he has come, not to abolish, but to fulfil 'the law and the prophets' (5:17). ${ }^{5}$ What the narrator has told the reader repeatedly, and what Jesus has acted out in his baptism and in the temptations, he now declares, but this declaration in itself introduces a new dynamic. Jesus vows by a negative statement followed by a positive statement that he fulfils 'the law and the prophets'. Now there is a new relationship between the Scriptures and Jesus' words. If Jesus' words are true, not only is he fulfilling the Scriptures, but he is also offering a new authoritative teaching, one that is related to the Scriptures and attested by the wondrous events reported in the first four chapters of the Gospel. Further, the fulfilment of the law portends coming events, which Jesus, as the new Moses, can declare to his followers: 'Truly I tell you, until heaven and earth pass away, not a letter, not a stroke of a letter will pass from the law until all is accomplished' $(5: 18)$. In this solemn pronouncement, Jesus claims personal authority ('I tell you' - 58 times in Matthew), invokes the solemnity of amen ('truly - 31 times in Matthew) to introduce the pronouncement, encompasses all eternity ('until heaven and earth pass away'), asserts the negative before the positive ('not ... not ... until ...'), and employs hyperbole ('not one letter, not one stroke of a letter').

In the next section of the Sermon, Jesus sets his words over against those of Scripture in the antitheses ('you have heard that it was said ... but I say'). The formulation 'you have

\footnotetext{
5. For a helpful overview of interpretations of 5:17-20 in relation to the Sitz im Leben of Matthew, see Viljoen (2012). W. Reinbold (2006:61-62) concludes from a study of the Law in Matthew (especially 5:20 and 23:2-3) that Matthew maintains that the authority of the teaching of the scribes and the Pharisees from the seat of Mose should be recognised and that Jesus' followers should be more righteous than the scribes and the Pharisees: 'Die Jünger sollen die Tora in ihrer Auslegung durch die "Schriftgelehrten und Pharisäer"' halten, und zwar in höherem Maße als sie. Sie sollen, wenn man so will, die besseren Pharisäer sein.'
}

heard that it was said' alludes to the Mosaic Law, using a passive circumlocution to avoid an explicit reference to God:

\begin{tabular}{|c|c|c|}
\hline 1. 5:21 & Murder & Exodus 20:13; Deuteronomy 5:17 \\
\hline 2. $5: 27$ & Adultery & Exodus 20:14; Deuteronomy 5:18 \\
\hline 3. $5: 31$ & Divorce & Deuteronomy 24:1-4 \\
\hline 4. 5:33 & Oaths & $\begin{array}{l}\text { Leviticus 19:12; Numbers 30:2; } \\
\text { Deuteronomy 23:21 }\end{array}$ \\
\hline 5. 5:38 & Vengeance & $\begin{array}{l}\text { Exodus 21:23-24; Leviticus 24:19-20; } \\
\text { Deuteronomy 19:21 }\end{array}$ \\
\hline $6.5: 43$ & Love and Hate & Leviticus 19:17-18 \\
\hline
\end{tabular}

The antitheses not only juxtapose Jesus' authority to the Mosaic Law, but they do so after Jesus has vowed that he did not come to abolish the law but to fulfil it. The reader has therefore been educated to understand Jesus' teachings as fulfilling Scripture, but the antitheses challenge the reader to understand how supplanting the scriptural commands with Jesus' teachings can be understood as fulfilment and not abolition. Jesus is characterised as the authoritative interpreter of scripture. As F. Scott Spencer (2010:368) aptly put it, 'Above all, Matthew's Jesus emerges as the church's authoritative biblical exegete and teacher.'

The point is driven home by later references. Jesus' authority is based on his identity as Son of David and Son of Abraham (from the genealogy), his identity as Son of God (from his birth), the Moses typology, his refusal to succumb to Satan's temptations, his appeal to and fulfilment of the scriptures, his empowerment by the Spirit, the miracles he performs, the authority he claims $(9: 2,6 ; 11: 27 ; 21: 23-27 ; 28: 18)$, the transfiguration, the recognition of the authority of his teachings, and ultimately the resurrection. ${ }^{6}$ As Ulrich Luz (1995:118) observes, "“authority" is a mark of Jesus' ministry altogether'.

The Sermon concludes with Jesus' admonition that those who hear his words and do them, are like a wise man (7:24-27). Jesus' words embody wisdom and often echo the wisdom tradition, take the form of proverbs or aphorisms, and employ

6.For a much more comprehensive discussion of Jesus' authority in Matthew see Lee and Viljoen (2010:66-71). 
images and metaphors found in the wisdom literature (cf. especially 11:19; 13:54; see Perdue 1986). The crowds who heard him, however, were astounded, the narrator reports, 'for he taught them as one having authority' (7:29) - the first reference to authority in the Gospel (cf. 8:9; 9:6, 8; 10:1; 21:23, $24,27 ; 28: 18)$. Francois P. Viljoen (2013) aptly characterises the integral relationship between righteousness, Torah, and the teachings of Jesus:

The norm for the disciples' conduct is based on a specific interpretation of the Torah. By following Jesus and his interpretation of the Torah, people find their identity as citizens of the kingdom of God. They should exercise their identity as citizens of this kingdom by acting righteously according to the precepts given by Jesus. Righteousness implies observing all that Jesus commanded (Mt 28:20). (p. 9)

Jesus' works confirm that he fulfilled the law and the prophets. The narrator comments that Jesus' healings 'fulfil what had been spoken through the prophet Isaiah' (8:17). Jesus' claims of authority soon meet opposition, however. Jesus, the Son of Man, 'has nowhere to lay his head' (8:20). Those who witnessed the exorcism of the demons from the two Gadarene demoniacs 'begged him to leave their neighborhood' (8:34). In the next scene, across the Sea of Galilee, when Jesus pronounces the paralysed man's sins forgiven, the scribes say to themselves, 'This man is blaspheming' (9:3; cf. 12:14, 24), but Jesus asserts, 'the Son of Man has authority on earth to forgive sins' (9:6). The crowd of spectators 'glorified God, who had given such authority to human beings' (9:8). The repetition of the word authority in this scene drives home the point, as do subsequent references. Jesus' teachings are like new wine (9:17). Those who acknowledge him, he will acknowledge before his Father (10:32-33). Indeed, Jesus even claims 'All things have been handed over to me by my Father' (11:27).

Whilst Jesus claims authority for his teachings, and the works he does confirm his authority, the Gospel does not lose sight of the fulfilment of Scripture. At various points in the mid-section of the Gospel, Jesus declares that the Scriptures are fulfilled, echoing the narrator's fulfilment formula in the early chapters:

11:9 'This is the one about whom it is written'

13:14 'With them indeed is fulfilled the prophecy of Isaiah'

15:7 'Isaiah prophesied rightly about you when he said ...'

Simultaneously, the narrator continues to affirm the fulfilment of Scripture:

12:17 'This was to fulfill what had been spoken through the prophet Isaiah'

13:35 'This was to fulfill what had been spoken through the prophet'

21:4 'This took place to fulfill what had been spoken through the prophet'

Jesus also charges that his opponents - those who do not accept the authority of his teachings - have not read or do not understand the Scriptures:
12:3 'Have you not read what David did ...?'

12:5 'Or have you not read in the law ...?'

19:4 'Have you not read ...?'

21:16 'Have you never read ...?'

21:42 'Have you never read in the Scriptures ...?'

22:31 'Have you not read what was said to you by God ...?'

By means of these rhetorical questions, Jesus advances his interpretation of the Scriptures in contrast to that of the Pharisees (see Spencer 2010:368). The question is repeated twice in Jesus' dispute with the Pharisees on Sabbath law and plucking grain on the Sabbath. Immediately thereafter Jesus cites Hosea 6:6 as a criterion for interpretation of the Law (see Hays 2005:180-182; Viljoen 2014, especially p. 232). The implication of these rhetorical questions is that Jesus' opponents oppose him because they do not know or heed the Scriptures. Because Jesus fulfils the Scriptures, the logic is that those who understand the Scriptures follow him, whilst those who oppose him do not. They also do not understand Jesus' parables, and thereby fulfil Isaiah's proclamation of judgement $(13: 13-15,19)$ : they listen, but do not understand; their ears are hard of hearing. They will not 'understand with their heart and turn' (13:15). Heeding the Scriptures requires proper understanding, which depends on the inclination of the heart and a readiness to understand.

Those who do not hear and understand, misinterpret the Scriptures with the result that they teach 'human precepts and doctrines' (15:9). The Scriptures teach that one must 'honor your father and your mother' (15:4; Ex 20:12; Dt 5:16), but the Pharisees and scribes 'break the commandment of God' for the sake of their tradition, which allows one to circumvent the command: 'God commanded ... but you say' (15:4-5). Again, the words of Scripture (Isaiah) have been fulfilled (15:7).

The people marvel at his wisdom (13:54), but the reader knows that Jesus talked with Moses and Elijah (17:3). When the Pharisees question him about divorce, Jesus asks if they have not read the teaching on marriage (19:4). Moses' command was due to their 'hardness of heart' (19:7-8). In its place Jesus declares a new law (19:9; cf. 19:17-21). Similarly, when someone asks him, 'What good deed must I do to have eternal life?' (19:16), Jesus answers by pointing him to the commandments (the Decalogue) first and then adds that if he wished to be teleios (cf. 5:48; 'perfect' - NRSV; or 'blameless' rendering the Hebrew tam, Job 1:1), he must 'go, sell your possessions, and give the money to the poor ... then come follow me' (Davies \& Allison 1988:560-563; Rensberger 2014).

When Jesus enters Jerusalem, Matthew is careful to underscore by event, Jesus' words, and the narrator's comments that what he did and taught in the holy city fulfilled the Scriptures, especially the psalms of ascent. His entry on 'a donkey and on a colt' fulfilled what had been spoken by the prophet (21:4-5). The crowds that followed him chanted the psalms of ascent (21:9; Ps 118:26). When 
Jesus 'cleansed' the temple, he quoted Isaiah 56:7 and Jeremiah 7:11. The children chanted, 'Hosanna to the Son of David' (21:15), which Jesus interpreted as fulfilment of Psalm 8:3 (21:16). The chief priests and the elders questioned Jesus regarding his authority (21:23). In response, Jesus indicted them by asking which of two sons did the will of their father. The son who does what he is told to do is better than one who only promises to do as he is told (21:28-31). His parable of the vineyard echoes the song of the vineyard on Isaiah 5 (Culpepper 1999). The implication of the parable is obvious. Have they never read the Scriptures (21:42)? Then he quotes the Scriptures once more (21:42; Ps 118:22-23).

Jesus' response to the Sadducees might serve as a paradigm for the entire Gospel, for, in both the pericope and the Gospel, there is a shift from the authority of the Scriptures to the authority of Jesus' words. The Sadducees raise a trick question based on what Moses said (22:23-28). Jesus responds that they are wrong because they know 'neither the Scriptures nor the power of God'. 'Have you not read?' (22:31). The crowd is astonished at his teaching (22:33). The point, having been repeated so many times and with such variations is clear: Jesus' teachings are based on the Scriptures and fulfil them. The opponents reject Jesus' teachings, because they do not understand ('have they not read?') the Scriptures.

At his arrest, it is Jesus (not the narrator) who says that Scripture must be fulfilled $(26: 54,56)$. The symphony of ideological points of view continues with the return to explicit commentary regarding fulfilment in 27:9: 'Then was fulfilled what had been spoken through the prophet Jeremiah.' The redundancy of expression, coming as it does from both Jesus and the narrator, strengthens the rhetorical effect.

Throughout the Gospel, Jesus' teachings emphasise the importance of doing right. Here James (1:22-25) and Matthew share an emphasis on the importance of obedience and doinga tilt toward a works righteousness. ${ }^{7}$ Those who do not heed Jesus' words act the part of a fool (7:26), like one who builds his house on sand. Wisdom is vindicated by her deeds (11:19). Jesus' 'yoke is easy' and his 'burden is light' (11:30), unlike the Pharisees who bind heavy burdens on others (23:4), but the expectation is still that the disciples will do what Jesus teaches. In response to the Pharisees' intent to find fault with Jesus, he defends his actions, saying 'it is lawful to do good on the Sabbath' (12:12). Likewise, whoever does the will of his Father in heaven belongs to his true family (12:50). Those represented by the good soil hear his word, understand it, and bear fruit, one hundred, sixty, and thirtyfold (13:23). When the Son of man comes, judgement will be meted out on the basis of what one has done (16:27). Jesus does not dispute the importance of doing good when the rich man asks him, 'what good deed must I do to inherit eternal life?' (19:16). Instead, he gives him a command. The morning after he pronounced judgement in the temple, Jesus curses the fig tree for not bearing fruit (21:19). The son who did the will

7.See Smith (1995:179-180) for suggestive comments on how Matthew is both simila to and different from John in this respect. of his father is the one who went into the vineyard, not the one who only promised to do so (21:28-32). Similarly, the wedding guests with whom the king is pleased, are not those who only accepted his invitation, but those who came to the banquet and who came wearing a wedding garment, that is, those who had done good works (22:2-13). Therefore, Jesus warns the crowds and his disciples to do as the scribes and Pharisees say, but not as they do (23:3). Be careful that no one leads you astray (24:4); be ready (24:44), for the wise and foolish maidens, the servants entrusted with talents, and the sheep and the goats are distinguished by what they do (25:1-46). Like the law and the prophets, Jesus' words will never pass away (24:35; cf. 5:18). Here the reader is cued to recall that Jesus said the same thing about the Law and the prophets earlier $(5: 18)$. Just as the authority of Scripture is eternal, so is the authority of Jesus' teachings. Those who would enter the kingdom must keep Jesus' teachings.

The last line of the Gospel completes the shift from the primacy of Scripture to the primacy of Jesus' words when the risen Lord announces: 'All authority on heaven and on earth has been given to me' (28:18). Having declared his authority, the risen Lord commissions his disciples, 'make disciples ... teaching them to obey everything that I have commanded you' (28:20). Because of Matthew's redundancy - the identification of Jesus with Scripture, the repetition of explicit commentary affirming the fulfilment of Scriptures, the repetition of claims for the authority of Jesus' words, and the repeated emphasis on the importance of doing - the reader is prepared for this final call to obey Jesus' teachings. The reader does not sense the absence of fulfilment formulae or references to the Law of Moses. The transference of authority is complete. Henceforth, Jesus' disciples will call others to live by Jesus' teachings. The words associated with this command are, strikingly and deliberately, words that are traditionally associated with the Scriptures. Moses 'commanded' (19:7), and Jesus instructed the man seeking eternal life to keep (19:17) the commandments. The use of these terms in reference to Jesus' teachings lends the authority of Scripture to Jesus' teachings, thereby validating Jesus' claim to authority. ${ }^{8}$

\section{Conclusion}

We have explored how Matthew uses the device of redundancy throughout the Gospel to communicate that the Scriptures have been fulfilled in Jesus' life and teachings. In defence of this claim of authority for Jesus' teaching, Matthew employs the narrator's explicit commentary, which is then echoed on the lips of Jesus; quotations of Scriptures; demonstrations of authority by means of Jesus' works, which often recall the works of Moses and the prophets; and debates over Jesus' authority. The Gospel begins with the repeated affirmation of the fulfilment of Scripture, but also

8.Donaldson (1985:179-188) and Volschenk (2010:7) interpret the climactic mountain scene as one that functions as the vehicle by which 'Zion expectations' (i.e. 'the gathering of the eschatological people of God and the locus of God's presence with his people') 'are transferred to Christ', but they do not identify the transfer of authority from the Scriptures to the teachings of Jesus that is associated with the progression from the Sermon on the Mount to the commissioning scene at the end of the Gospel, perhaps because Donaldson (1985:111-115) denies any Moses typology in Matthew (see Allison 1993; Rogers 2012). 
TABLE 2: The transfer of authority in Matthew.

\begin{tabular}{|c|c|c|c|}
\hline Variable & Matthew 5-7 & Matthew 8-25 & Matthew 26-28 \\
\hline \multicolumn{4}{|l|}{ Jesus' Fulfillment of Scripture } \\
\hline Narrator's Comments & - & $8: 17 ; 12: 17 ; 13: 35 ; 21: 4$ & $27: 9$ \\
\hline Jesus' Declarations & $5: 17-18$ & & $26: 54,56$ \\
\hline Demonstrations by Jesus' Works & - & $21: 4-5$ & 21:1-11 \\
\hline \multicolumn{4}{|l|}{ The Authority of Jesus' Teachings } \\
\hline Narrator's Comments & $7: 28-29$ & $13: 54$ & \\
\hline Jesus' Interpretation of Scripture & - & $11: 9 ; 13: 14 ; 15: 7 ; 19: 9,16-22 ; 21: 13,16-17,42$ & - \\
\hline 'Have you never read ...?’ & - & $12: 3,5 ; 19: 4 ; 21: 16,42 ; 22: 31$ & - \\
\hline Demonstrations by Jesus' Works & - & $17: 3 ; 21: 12-14,19$ & - \\
\hline Responses Affirming Jesus' Authority & $7: 28$ & $9: 8 ; 13: 54 ; 21: 11,15 ; 22: 33$ & - \\
\hline Debates over Jesus' Authority & & $9: 3 ; 12: 24 ; 21: 23-27$ & \\
\hline
\end{tabular}

its enduring authority. In the Sermon on the Mount, Jesus declares his own authority both over against and in fulfilment of Scripture. This dialectic fuels conflict over Jesus' authority, which the religious leaders challenge repeatedly. In response, Jesus asserts that if they understood the Scriptures - indeed, if they had read the Scriptures - they would understand that what he did fulfilled the law and the prophets. By the end of the Gospel the transfer is complete: Jesus' words now carry the authority of Scripture. ${ }^{9}$ See Table 2.

As William Loader (1992; 2012 n.d.) observed in a forthcoming article on the soteriology of the Gospel of John, echoing his earlier work on John's Christology:

There has been a radical break and discontinuity based on the high christological claims made by these Jews and others in the community who became Christ-believers, to the extent that Jesus was effectively made to usurp the role of Torah and was identified as alone the Word, light and life, and bearer of food and water. The original Jewish spirituality remains, however, a controlling factor in this, so that effectively the spirituality does not change, but only the way it is mediated. Ironically this even affects the discontinuous element, the role of Jesus, because he is portrayed less as a human being (never denied) and more as embodiment of God's Word in a way that then almost merges him into the being of God, analogous to Jewish understanding of Torah/Word/Wisdom.

In Matthew, however, whilst Jesus' teachings fulfil and replace the Torah, Jesus himself is not made to embody or take the Torah's place as the new locus of revelation as is the case in John, but rather Jesus is the new Moses whose teachings fulfil the Torah and now carry eternal authority. Still the essential soteriological structure remains strikingly similar in Judaism and Matthew (and John): God's revelation, through Moses or Jesus, the covenantal expectation of obedience to this revelation ('observe all that I have commanded you'), and the assurance of blessing for

g.Others have reached very similar conclusions from different lines of argument. É. Cuvillier (2009:159) contends: 'The First Gospel's referent has been displaced: the pillar which sustains Matthew's theology-and therefore his religious identity-is no longer primarily the Law and obedience to its commandments, but the Messiah and his teaching.' Similarly, R.B. Hays (2005:189) has argued that the Gospel of Matthew constitutes 'a striking reconfiguration of Israel's Scripture, particularly when we recognise that this hermeneutical transformation depends at every poin on Matthew's insistence that it is the singular authority of the one man Jesus, Emmanuel, that generates, embodies, and justifies these transfigurations of the tradition'. Rogers (2012:396) concludes: 'Throughout, Matthew has shown that Jesus has greater authority than Moses, especially in the area of teaching. those who are faithful, and judgement for those who do not heed the authority of this revelation. ${ }^{10}$

The meaning of Emmanuel lies precisely in the eternal authority of Jesus' teachings: Jesus' words will never pass away. The Gospel reaches the end towards which it moves from its beginning. Jesus has fulfilled the law and the prophets by bringing a new teaching with 'all authority'.

\section{Acknowledgements Competing interests}

The author declares that he has no financial or personal relationship(s) that may have inappropriately influenced him in writing this article.

\section{References}

Allison, D.C., Jr., 1993, The new Moses: A Matthean typology, Wipf \& Stock, Eugene, OR.

Anderson, J.C., 1994, Matthew's narrative web: Over, and over, and over again Sheffield Academic Press, Sheffield. (JSNT Supplement Series, 91).

Balz, H., 1972, 'tessarakonta', in G. Kittel (ed.), TDNT, transl. G.W. Bromiley, vol. 8, pp. 127-139, Wm. B. Eerdmans, Grand Rapids.

Barthes, R., 1974, S/Z, transl. R. Miller, Hill \& Wang, New York.

Brown, R.E., 1983, The birth of the messiah, Doubleday, Garden City, NY.

Cherry, C., 1957, On human communication, MIT Press, Cambridge.

Culpepper, R.A., 1999, 'Parable as commentary: The twice-given vineyard (Luke 20:9-16)', Perspectives in Religious Studies 26(2), 147-168.

Culpepper, R.A., 2013, 'The weave of the tapestry: Character and theme in John', in C.W. Skinner, (ed.), Characters and characterization in the Gospel of John, pp. 18-35, Bloomsbury, London. (LNTS, 461).

Cuvillier, É., 2009, 'Torah observance and radicalization in the First Gospel. Matthew and first-century Judaism: A contribution to the debate', NTS 55(2), 144-159. $\mathrm{http}: / / \mathrm{dx}$.doi.org/10.1017/S0028688509000101

Davies, W.D. \& Allison, D.C., 1988, A critical and exegetical commentary on the Gospel according to Saint Matthew, vol. 1., T\&T Clark, London. (International Critical Commentary)

Donaldson, T., 1985, Jesus on the mountain: A study in Matthean theology, JSOT Press, Sheffield.

Hays, R.B., 2005, 'The Gospel of Matthew: Reconfigured Torah', HTS Teologiese Studies/Theological Studies 61, 165-190. http://hts.org.za/index.php/HTS/ article/view/447/346

Kittel, G., 1964, 'erēmos', in G. Kittel (ed.), TDNT, trans. G.W. Bromiley, vol. 2, pp. 657-660, Wm. B. Eerdmans, Grand Rapids.

10.Loader (n.d.) makes the following comments about John's soteriology: "It is good Judaism: God's goodness offers a relationship which one accepts by taking on the gift of God's word in Torah. The christological version is the same, either by identifying Jesus with Torah, or by portraying Jesus as God's new initiative, to offer the life and truth to which Torah pointed. In both Judaism and in the christological version the offer and the response are essentially the same or of the same kind: believing, accepting the offer, entering the relationship, living out the consequences, and enjoying the privileges of being God's children.' 
Lee, K. \& Viljoen, F.P., 2010, 'The ultimate commission: The key for the Gospel according to Matthew', Acta Theologica 30(1), 64-83.

Loader, W.R.G., 1992, The christology of the fourth Gospel: Structure and issues, 2nd ed., BET 23, Peter Lang, Frankfurt.

Loader, W.R.G., 2012, 'The law and ethics in John's Gospel', in J.G. van der Watt \& R. Zimmermann (eds.), Rethinking the ethics of John: 'Implicit ethics' in the Johannine writings, pp. 143-158, Mohr Siebeck, Tübingen. (Kontexte und Normen neutestamentlicher Ethik/Contexts and norms of New Testament ethics, 3).

Loader, W.R.G., n.d., 'The significance of the prologue for understanding John's soteriology', Mohr Siebeck, Tübingen. (Forthcoming).

Lohr, C.H., 1961, 'Oral techniques in the Gospel of Matthew', CBQ 23, 403-435.

Luz, U., 1995, The theology of the Gospel of Matthew, transl J.B. Robinson, New Testament Theology, Cambridge University Press, Cambridge.

Luz, U., 2007, Matthew 1-7, transl. J.E. Crouch, Hermeneia, Fortress Press, Minneapolis.

Perdue, L.G., 1986, 'The wisdom sayings of Jesus', Forum 2(3), 3-35.

Reinbold, W., 2006, 'Das Mattäusevangelium, die Pharisäer und die Tora', Biblische Zeitschrift 50(1), 51-73.

Rensberger, D. 2014. 'Completed love: 1 John 4:11-18 and the mission of the New Testament Church', in R. A. Culpepper \& P.N. Anderson (eds.), Communities in dispute: Current scholarship on the Johannine epistles, pp. 237-271, SBL Press, dispute: Current scholarship on the Johanni.
Atlanta. (Early Christianity and its literature).

Rogers, T., 2012, 'The great commission as the climax of Matthew's mountain scenes', Bulletin of Biblical Research 22, 383-398.

Saunders, S.P., 2010, Preaching the Gospel of Matthew, Westminster John Knox, Louisville.

Smith, D.M., 1995, The theology of the Gospel of John, New Testament Theology, Cambridge University Press, Cambridge. http://dx.doi.org/10.1017/ CBO9780511819865
Spencer, F.S., 2010, 'Scripture, hermeneutics, and Matthew's Jesus', Interpretation 64 368-378. http://dx.doi.org/10.1177/002096431006400404

Stendahl, K., 1964, 'Quis et Unde? An analysis of Mt 1-2', in W. Eltester (ed.) Judentum, Urchristentum, Kirche, pp. 94-105, Töpelmann, Berlin. (Festschrift for J. Jeremias, BZNW 26).

Sternberg, M., 1988, The poetics of biblical narrative: Ideological literature and the drama of reading, Indiana University Press, Bloomington.

Suleiman, S.R., 1980, 'Redundancy and the "readable" text', Poetics Today 1, 119-142. http://dx.doi.org/10.2307/1772415

Viljoen, F.P., 2007, 'Fulfilment in Matthew', Verbum et Ecclesia 28, 301-324. http:// dx.doi.org/10.4102/ve.v28i1.109

Viljoen, F.P., 2012, 'Matthew's Sitz im Leben and the emphasis on the Torah', Acto Theologica 32(2), 254-276.

Viljoen, F.P., 2013, 'Righteousness and identity formation in the Sermon on the Mount', HTS Teologiese Studies/Theological studies 69(1), Art. \#1300, 10 pages. http://dx.doi.org/10.4102/hts.v69i1.1300

Viljoen, F.P., 2014, 'Hosea 6:6 and identity formation in Matthew', Acta Theologica 34 214-237. http://dx.doi.org/10.4314/actat.v34i1.12

Volschenk, G.J., 2010, 'Review article: The mountain motif in the plot of Matthew', HTS Teologiese Studies/Theological Studies 66(1), Art. \#326, 9 pages. http:// dx.doi.org/10.4102/hts.v66i1.326

Witherup, R.D., 1992, 'Functional redundancy in the Acts of the Apostles: A case study', JSNT 48, 67-86. http://dx.doi.org/10.1177/0142064x9201504804

Witherup, R.D., 1993, 'Cornelius over and over and over again: "Functional redundancy" in the Acts of the Apostles', JSNT 49, 44-66. http://dx.doi. org/10.1177/0142064×9301504904

Wittig, S., 1973, 'Formulaic style and the problem of redundancy', Centrum 1, 123-136 